\title{
Article \\ The Impact of new technologies on wages in Colombia: An analysis with the 2018 quality-of-life survey.
}

\author{
Fernando Barrios ${ }^{1}$, Martha Patricia Castellanos², Diana Alvarez ${ }^{3,}$, Milena Riveros $^{4 *}$
}

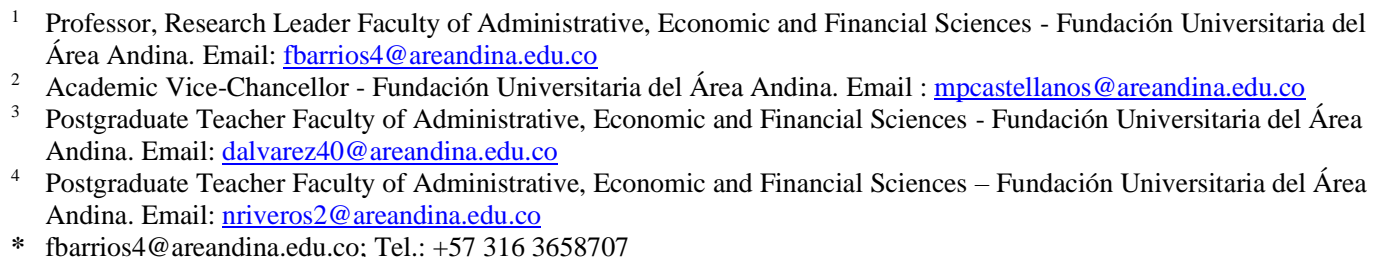

\begin{abstract}
This document evaluates the impact of computer use on wages in Colombia in 2018. For this analysis, a Propensity Score Matching model is used to evaluate the impact of the use of learning technologies on the wages and years of education of Colombians, based on the 2018 quality of life survey. The results show that the use of the computer, laptop, tablet, internet, transferred files, Excel and radio for learning have a positive impact on the wages of Colombians. This research allows a better understanding of the technological effects on wages and provides information for the design of public policies in the development of technological skills.
\end{abstract}

Keywords: Technological skills, wages.

\section{Introduction}

The effects of technology on employment and wages are a source of controversy [1]. Some see that jobs are in a continuous process of automation and that this will generate job losses in all economic sectors [2-3]. On the other hand, some claim that technology will increase labor demand and, therefore, employment and wages [4]. Therefore, the objective of this document is to analyze the effect of the use of computers on wages and educational levels in Colombia.

Some studies affirm that technology increases the efficiency of work in the production process under the hypothesis about the existence of a wage premium for the use of the computer at work [5-6]. However, its effects on net employment and wages are ambiguous because they depend on the skills and tasks performed by workers [7-8]; additionally, the studies that attempt to verify this statement have been widely criticized for the bias in the selection of workers. the sample which prompts to carry out studies where these methodological inaccuracies are corrected [9]. In general, the empirical evidence shows that technology replaces work in routine tasks but is a complement that depends on the skill levels of the work [10] and the solution of complex problems [11-12]. In addition, several studies found that working (workplace) more using the computer has greater remuneration [13]. However, it is to be expected that as the requirement to use a computer at work increases, the wage premium associated with the use of it will decrease [14-15].

In developed countries, the use of technology such as modern machines and systems increases the demand for skilled workers [16-17]. Furthermore, the frequent use of computers in the workplace had a positive effect on the productivity and wages of workers [18-19]. In addition, Arabsheibani, Marin \& Wadsworth [20] between 1980 and 1990 found that UK workers increased use of computers had more education but less experienced labor, while Allen [21] states that wage growth experienced workers it is higher in R\&D-intensive industries than in non-intensive ones. For the period 1997-2001, the study by Lee \& Kim [22] affirms the existence of a significant salary premium related to the use of the Internet at work.

In Latin America, research shows a positive effect of the use of technologies on wages. Specifically, to Mexico, several authors find that technology has a greater impact on wages of workers with more education [23-24]. Also in Ecuador, Oosbterbeek \& Ponce [25] found that computer use increases the wage premium by around 10\%. Similarly in Chile [26] found that the use of computers increased the productivity and wage premium for workers between 2000 and 2006. In the case of Uruguay, a study in 2013, the hypothesis about the effect of the use of 
technology on wages was tested, finding that there is no significant effect on the wage distribution [27]. Another study applied to the case of Brazil, Chile, Costa Rica, Honduras, Mexico, and Paraguay, for the period 2005-2007, refers to a problem in this type of analysis due to the bias of the sample, showing a double causality between the use of the Internet and income [28].

In Colombia, Martin [29] found a positive correlation between the use of the internet and the incomes of workers. However, it shows that the effect of the internet on wages depends on the activities carried out on the web, the intensity of use, and the occupation of each worker. Specifically, the workers with the highest salary benefits from the use of the Internet are those who work in lower-skilled jobs (agriculture and mining). Whereas workers with higher skills obtain less gain in salary for the use of the Internet.

The main contribution of this article to the Colombian literature is the generation of empirical evidence of the impact of the use of computers, laptop, tablet, internet, transferred files, Excel and radio for learning on wages in Colombia. In addition, this research complements the results of previous research that have analyzed the impact of Internet use on productivity and earnings of workers in different economic sectors in Colombia [30]. The effects of the use of technologies on wages are evaluated with a propensity score matching (PSM) model, in a sample of 283,174 people who register in the Quality-of-Life Survey (ECV).

This document is divided into four sections. In the first, there is a review of the literature on the effects of technology on wages. The second section contains the Strategy of identification through which the impact of the use of computers, laptop, tablet, internet, transferred files, Excel and radio for learning on wages is evaluated. This section has the econometric identification strategy based on the impact analysis using pairing and the results of the econometric estimation. Finally, the third section has the results, and the fourth section presents the conclusions and discussions.

\subsection{Literature Review}

Technology increases the efficiency of work in the production process. However, their effects on net employment and wages are ambiguous because they depend on the skills and tasks performed by workers [31-33]. In general, empirical evidence shows that technology replaces work in routine tasks but is a complement to tasks involving the solution of complex problems [34-36], Acemoglu, 1998). In addition, several studies find that workplaces with greater use of the computer have higher remuneration [37]. However, it is to be expected that as the requirement for the use of computers at work increases, the wage premium associated with the use of computers will decrease [38].

In developed countries, the use of technology, such as modern machines and computer systems, increased the demand for skilled workers [39-41]. In addition, the frequent use of computers in workplaces had a positive effect on productivity and workers' wages [42 - 43]. In addition, Arabsheibani et al [44] found between 1980 and 1990 that in the United Kingdom workers with greater use of computers had more education but less work experience.

In Latin America, research shows a positive effect of the use of technologies on wages. Specifically, for Mexico, several authors find that technology has a greater impact on the wages of workers with more education [45-46] Torres and Félix, 2017). Also in Ecuador, Oosbterbeek and Ponce [47] found that the use of the computer increases the wage premium by about $10 \%$. Similarly in Chile, Benavente, Bravo, and Montero [48] found that the use of computers increased the productivity and wage premium of workers between 2000 and 2006. In Colombia, Martín [49] found a positive correlation between internet use and workers' incomes. However, it shows that the effect of the internet on wages depends on the activities they perform on the web, the intensity of use, and the occupation of each worker. Specifically, the workers with the greatest benefits from using the internet in wages are those who work in lower-skilled jobs (agriculture and mining). While workers with higher skills earn less in salary from the use of the internet.

Technological changes generate changes in the qualification structure of demand, which leads to large changes in the structure of relative wages, especially a huge increase in the relative wages of workers with a high educational level [50]. In addition, a high proportion of skilled workers in the workforce implies a large market for skills-complementary technologies and encourages a more rapid improvement in the productivity of skilled workers [51]. As a result, an increase in skill supply lowers the skill premium in the short term, but then induces a skill-biased technical change and increases the skill premium, possibly even above its initial value. 
Part of this technological change has been induced using information technologies and the use of novel artifacts, such as computers. About, Author, Levy, and Murnane [52] indicate that computerization alters the demands of job skills, replacing workers in performing cognitive and manual tasks that can be accomplished by following explicit rules; and complements workers in performing complex communication tasks and solving non-routine problems. Thus, computerization is associated with a lower amount of workforce for routine manual and routine cognitive tasks and a higher work contribution from non-routine cognitive tasks changes in demand for education. It can explain the change in the estimated relative demand for college work or the change in tasks within nominally identical occupations.

Beaudry, Doms, \& Lewis [53] moreover, show that the introduction and dissemination of personal computers is generally considered a technological revolution that create a link between the adoption of PC, educational attainment, and return to skills, and where the cities are adjusting so unlike the advent of more skill-intensive means of production, and that returns to skills will increase more where skills are abundant, and performance is low. From the labor market, the technology takes a form of factor augmentation that, by complementing high- or low-skilled workers, can generate skill-biased demand shifts, such as significant drops in the real wages of lowskilled workers, particularly men low-grade [54]. However, the recent changes in the distribution of income and employment is molded by interactions between workers ' skills, job tasks, evolving technologies, and changing commercial opportunities.

Technologies such as information and communication technologies (ICT) can polarize labor markets to the increasing demand for people with a high educational level at the expense of midlevel, with little effect on workers with low educational attainment. Thus, the fastest-growing ICT industries are likely to shift the demand from workers with secondary education to workers with higher education, in line with ICT-based polarization [55]. Consequently, the increase in the use of information and communication technologies leads to a growing demand for skilled labor concerning low-skilled labor, showing that there is indeed an effect of the adoption of information and communication technologies. on the demand for more skilled workers. In some sectors, the results would be driven by an increasing sophistication of manual workers due to the organizational adjustments derived from the adoption of information and communication technologies [56]. Even though the slower growth in employment during the last three decades is explained by an acceleration of the displacement effect, especially in manufacturing, a weaker reinstatement effect, and growth in productivity slower than in previous decades [57].

There is literature that shows the positive effect of the use of technologies on wages. For example, Krueger [58] examines whether workers who use a computer at work earn a salary higher than similar workers who do not use a computer at work suggesting that workers who use computers at work earn between 10 and 15 percent more wages. Furthermore, the expansion of computer use in the 1980s may account for between one-third and one-half of the increase in the rate of return to education. DiNardo, and Pischke [59], confirm that the wage differential estimate associated with using computers in Germany is very similar to the US differential. They also measure large differences for the use of calculators, telephones, pens, or pencils at work, or for those who work seated. The authors argue these findings shed some doubts about the literal interpretation of the wage differential using computers reflecting the true yields of the use or the ability of computers. Doms, Dunne, and Troske [60] show how plant-level wages, occupational mix, workforce education, and productivity vary with the adoption and use of new factory automation technologies, such as programmable controllers, computer-automated design, and numerically controlled machines. The authors' cross-sectional results show that plants using many new technologies employ more educated workers; employ relatively more managers, professionals, and precision craftsmen; and therefore, pay higher wages.

Allen [61] also shows that the wage differences by industry are related to the intensity of $\mathrm{R} \& \mathrm{D}$, the use of high technology capital, the current state of technology, the growth of total factor productivity, and the growth of the capital-labor ratio. The returns to education are higher in industries that are intensive in R\&D and high-tech capital and technological variables account for 30 percent of the increase in the wage gap between college graduates and secondary. Also, Arabsheibani, Emami, and Marin [62] indicate that not only returns using computers are positive, but it is also important to correct for selection bias in the sample.

Zoghi \& Pabilonia [63] (2007) Using the Canada Employee and Workplace Survey and controlling for individual and establishment fixed effects, we found that within a year of adopting a computer, the average worker earns a salary 3.6\% higher than an average worker who did not use a computer. The returns are even higher for managers and professionals, highly skilled workers, 
and those with significant prior computer experience. Employees who adopt computers for use with applications that require high cognitive skills obtain the highest returns.

Störmer, et al. [64] shows that the use of information technology (ICT) at work has implications for wage differentials in Mexico, showing a wage disparity for people with computer skills related to working well as for those who have experience using a computer. The amount that workers are paid based on their computer skills varies according to the type of occupation in which they work. Finally, Akerman, Gaarder, and Mogstad [65] suggest that the broadband Internet improves (worsens) the results of the labor market and productivity of skilled workers (unskilled) and a possible explanation suggests that the adoption of the band Broad in companies complements skilled workers in performing non-routine abstract tasks and replaces unskilled workers in performing routine tasks.

The Propensity score matching technique (PSM) has been frequently used in labor market research for Latin America to find positive impacts. In this regard, Caliendo and Kopeinig [66] state that the Propensity Score Matching (PSM) technique has become a popular approach to estimate the causal effects of treatment. It is widely applied when evaluating labor market policies, but empirical examples can be found in many different fields of study. An example is Benavente, Bravo, and Montero [67]. This article presents solid evidence on the impact of the use of computers in the workplace in Chile for the period 2000-2006. The main contribution is to present evidence in a developing country using matching techniques, assuming a homogeneous treatment effect. Then the salary impact is measured through the core and nearest neighbor estimator. The results consistently show that there is a premium associated with the use of computers in the workplace, which is interpreted as an increase in the productivity of the person derived from the inclusion of an additional factor of production, that is, the computer. All of this is consistent with a model where computer penetration decreases this premium, something that has happened in Chile during this period. Indeed, estimates show a premium of around $26 \%$ for 2000 , but in 2006 it dropped to $16 \%$. Similarly, Navarro [68] uses matching techniques to examine the impact of Internet use on individual income in six Latin American countries using recent household survey data. Given its different patterns of Internet use and its implications, the analysis is carried out for salaried and self-employed workers separately. While salaried users primarily access the Internet at work, selfemployed users primarily access the Internet elsewhere. Therefore, the returns from Internet use for salaried workers may be associated not only with individual characteristics but also with those of the workplace.

The results indicate a large effect of Internet use on the income of both groups of workers in most of the countries studied. These returns are high compared to estimates for industrialized countries. This could be explained by the much lower prevalence of Internet use in the region by international standards. Also, since the estimates are based on cross-sectional data, they may not fully control for people's characteristics before Internet adoption. This requires the need for panel data on the diffusion of new ICTs in the region. Finally, Martín [69] uses propensity score matching and data from household surveys to estimate the effect of the Internet on wages in Colombia. The empirical results confirm that there is a positive and statistically significant relationship between Internet use and income in this country. Based on evidence gathered in developed countries in previous studies, empirical results also suggest that workers in the middle of the skill distribution receive the lowest wage premium for using the Internet. However, contrary to evidence from developed countries, low-skilled workers in Colombia enjoy the highest wage premium from Internet use, illustrating the potential of new technologies to address inequality gaps between occupations.

In contrast, there are some negative and mixed results of the use of technology on wages. Novella, Alvarado, Rosas, and Gonzalez Velosa [70] state that estimates of the impact of the intensity of computer use are also small and, in most cases, negligible. Taken together, also in the context of a developing country, we find no evidence in favor of the computing premium that reflects a causal impact. Silva M. [71], through the use of quantile regressions and Mincer salary equations, tested the hypothesis that the mere use of these technologies and the heterogeneity in the specific skills to do so does not have a significant effect on the salary distribution of Uruguay in 2013. The results found do not provide sufficient evidence to reject the said hypothesis, nor do they suggest the existence of significant differences in the effects of the different variables commonly associated with wages between those individuals who use ICT in their jobs and those who do not. Frey and Osborne [72] provide evidence that wages and educational level exhibit a strong negative relationship with the probability of computerization of an occupation.

Likewise, Lee and Kim [73] indicate that there is little relationship between Internet use and its effect on wages, while the relationship between computer use and wages is clearer. Dutz, 
Mation, O'Connell, and Willig [74] find that greater access to the Internet has no statistically significant net effect on aggregate employment and has a negative effect on average wages, a reduction in measures of dispersion wage. In the manufacturing sector, Internet access induces positive effects on employment and wages in medium and high-skilled occupations.

This document explores the use of different technologies such as the use of desktop computers, laptops, use of computer programs, and office automation, as well as the internet and radio for learning, on the wages of Colombians. In this way, we use a series of traditional and novel resources (the computer, laptop, tablet, internet, transferred files, Excel and radio for learning) to verify differentiating impacts in the use of learning acquired by different means. The main contribution of this article to the Colombian literature is the generation of empirical evidence of the impact of the use of computers, laptop, tablet, internet, transferred files, Excel and radio for learning on wages in Colombia. In addition, this research complements the results of previous research that has analyzed the impact of internet use on the productivity and earnings of workers in different economic sectors in Colombia.

\section{Materials and Methods}

The study of the impact of computer use on wages has an endogeneity problem that leads to biased results. This is because the most skilled workers have higher incomes, and it is they who have the greatest ability and use of the computer. To reduce this endogeneity a little, the effects of computer use on wages in Colombia are evaluated with the Propensity Score Matching model. This pairing model allows you to find for each worker who uses a computer (treated) another identical worker, except that he does not use a computer (control). However, this econometric strategy assumes the use of computers is only determined by observed variables.

The idea of matching is to find a "clone" of everyone treated in the control group and contrast the outcome variable of both. An individual with the same observable characteristics and with a sufficiently close probability of participation is defined as a "clone". Thus, the objective of this technique is to weigh the observations of the control group so that the distribution of observable characteristics is as close as possible to that of the treatment group.

In this way, the method is to find:

$$
\tau_{A T T}=E[Y(1) \mid D=1]-E[Y(0) \mid D=1]
$$

Where $\tau_{A T T}$ is the mean effect of treatment on the treated. $E[Y(1) \mid D=1]$ is the mean value of the result variable Y (1) (Wages) given that he uses the computer in his work. Also, E [Y (0)| D = $1]$ is the hypothetical or counterfactual situation (i.e. the expected value of the results variable $Y(0)$ ) for the individuals in the treatment group who did not receive technological skills and $\mathrm{D}=1$ means that the workers belong to the treatment group.

We can use the $X$ to estimate the probability of selection for treatment $P(D=1 \mid X)=P(X)$-using a binary probit or logit model in the case of treatment, and this probability is used to find similar companies in the two groups (treated and control). The estimator (PSM) for the mean effect of treatment on treated is:

$\tau_{A T T-P S M}=E[Y(1) \mid D=1, P(X)]-E[Y(0) \mid D=0, P(X)]$

Assuming conditional independence (in the propensity score $\mathrm{P}(\mathrm{X})$ ) of the outcome variables concerning treatment, this estimator is unbiased. An important condition in addition to the use of PSM, in addition to the so-called conditional independence, is that there are sufficient individuals of treatment and control in the common stand. More formally, we need $0<P(D=1 \mid X)<1$. This condition ensures that individuals with the same $\mathrm{X}$ values have a positive probability of being both participants and non-participants in the use of technological skill, and we avoid predicting perfectly whether an individual belongs to the control group or the treatment group.

In this way, the propensity score matching kernel structure uses:

$A T T=E\{E[Y 1 \mid D=1, p(X \mid C)]-E[Y O \mid D=0, p(X \mid C)] \mid D=1\}$

Where $p(X \mid C)$ is the Probability of the use of new technologies given $C$ covariates. $Y 1$ is the labor result for individuals who use new technologies and $Y 0$ the labor result for individuals who do not use new technologies. D is the indicator of whether or not the individual uses the technology and 
C collects different covariates: Age, gender, language, years of use of technologies, education, occupation, race, happiness or satisfaction in health, the effectiveness of use, anxiety about use, fluid intelligence.

\section{Results}

We apply propensity score matching techniques (PSM) to evaluate the impact of the use of the computer, laptop, tablet, internet, transferred files, Excel and radio for learning on the wages of Colombians. Data does not derive from a random, natural, or controlled, experiment. For that reason, econometric techniques such as discontinuity regression design cannot be used. Therefore, we used propensity score matching (PSM), to avoid potential selection bias. We implement the Kernel propensity score matching method to adjust for pre-treatment observable differences between a group of treated and a group of untreated.

For this purpose, we explore a database of individuals from the The Quality-of-Life Survey (ECV). The Quality-of-Life Survey (ECV) collects information on different aspects and dimensions of household well-being and living conditions, including topics such as access to public, private, or communal goods and services, health, education, comprehensive care for children under 5 years of age, technology, among others. The consideration of these aspects makes it possible to carry out further analyses of the factors that explain the different standards of living existing in society. In the chapters on technological skills, you will find the closest thing to the use of technological skills.

The probability that people will or will not use new technologies are related to several variables in the survey:

- Frequent use of laptop

- Frequent use of desktop computers

- Frequent use of Tablet

- Frequent use of the Internet

- Frequent use of the Internet for learning.

- Use of specialized programming language

The variable of interest is wages, measured as the income that individuals receive for giving their workforce to companies and the educational years achieved by individuals. Some studies show that the use of ICT has affected the labor market where the demands in terms of training constitute income barriers [75].

Table 1: Descriptive Statistics.

\begin{tabular}{lrrrrr}
\hline Variable & Obs & Mean & Std.Dev. & Min & Max \\
\hline Age & 283000 & 32.52 & 21.748 & 0 & 105 \\
Sex & 283000 & .491 & .5 & 0 & 1 \\
Overall satisfaction & 210000 & 8.202 & 1.782 & 0 & 10 \\
Education mother (years) & 168000 & 4.898 & 3.783 & 1 & 10 \\
Education father (years) & 209000 & 5.194 & 3.808 & 1 & 10
\end{tabular}

Linglab: Wages in logarithms

4860413.399

$1.567 \quad 4.58517 .728$

Level education (years)

$188000 \quad 4.544 \quad 2.662$ 


\begin{tabular}{|c|c|c|c|c|}
\hline Use Laptop & 261000 & 4.388 & 1.31 & 1 \\
\hline Use Tablet & 261000 & 4.826 & .737 & 1 \\
\hline Use The Internet & 261000 & 3.192 & 1.819 & 1 \\
\hline Use Computer every day & 261000 & .083 & .275 & 0 \\
\hline Use laptop every day & 261000 & .074 & .261 & 0 \\
\hline Use Tablet every day & 261000 & .018 & .132 & 0 \\
\hline Use The Internet every day & 261000 & .302 & .459 & 0 \\
\hline Use Radio & 261000 & 3.218 & 1.831 & 1 \\
\hline Usa Radio every day & 261000 & .313 & .464 & 0 \\
\hline
\end{tabular}

Use The Internet for learning

$283000 \quad .164$

$\begin{array}{lll}.371 & 0 & 1\end{array}$

Use Radio for learning

$283000 \quad .019$

.138

$\begin{array}{ll}0 & 1\end{array}$

Use Excel language

$92359 \quad .504$

.5

Use Transfer files

$92359 \quad .566$

$\begin{array}{lll}.496 & 0 & 1\end{array}$

Use computational Programs

$92359 \quad .322$

.467

Use language of programming

$92359 \quad .098$

.298

$0 \quad 1$

Source: Author's calculations based on ECV 2018 
Table 2. Probit models: marginal effects

\begin{tabular}{|c|c|c|c|c|c|c|c|c|c|c|}
\hline & (1) & (2) & (3) & (4) & (5) & (6) & (7) & (8) & (9) & (10) \\
\hline VARIABLES & Use Laptop & Use Tablet & $\begin{array}{c}\text { Use } \\
\text { Computer }\end{array}$ & $\begin{array}{l}\text { Use The } \\
\text { Internet }\end{array}$ & Excel & Transfer & computational & language & $\begin{array}{c}\text { Internet educ } \\
\text { Learning }\end{array}$ & $\begin{array}{l}\text { Radio educ } \\
\text { learning }\end{array}$ \\
\hline Age & $\begin{array}{c}-0.00151 * * * \\
(3.33 \mathrm{e}-05)\end{array}$ & $\begin{array}{c}-0.000154 * * * \\
(1.59 \mathrm{e}-05)\end{array}$ & $\begin{array}{c}-0.00135 * * * \\
(3.47 \mathrm{e}-05)\end{array}$ & $\begin{array}{c}-0.00595 * * * \\
(6.88 \mathrm{e}-05)\end{array}$ & $\begin{array}{c}-0.00207 * * * \\
(0.000187)\end{array}$ & $\begin{array}{c}-0.00347 * * * \\
(0.000179)\end{array}$ & $\begin{array}{c}-0.00228 * * * \\
(0.000185)\end{array}$ & $\begin{array}{c}-0.000279 * * \\
(0.000123)\end{array}$ & $\begin{array}{c}-0.00305^{* * *} \\
(4.08 \mathrm{e}-05)\end{array}$ & $\begin{array}{c}-5.28 \mathrm{e}-05 * * \\
(2.14 \mathrm{e}-05)\end{array}$ \\
\hline Sex & $\begin{array}{c}0.0118 * * * \\
(0.00116)\end{array}$ & $\begin{array}{l}0.000996 * \\
(0.000533)\end{array}$ & $\begin{array}{l}0.00238^{*} \\
(0.00123)\end{array}$ & $\begin{array}{c}-0.0102 * * * \\
(0.00231)\end{array}$ & $\begin{array}{c}0.0395 * * * \\
(0.00520)\end{array}$ & $\begin{array}{c}0.0486 * * * \\
(0.00498)\end{array}$ & $\begin{array}{c}0.0867 * * * \\
(0.00525)\end{array}$ & $\begin{array}{r}0.0537 * * * \\
(0.00376)\end{array}$ & $\begin{array}{c}-0.0129 * * * \\
(0.00131)\end{array}$ & $\begin{array}{l}-0.000142 \\
(0.000734)\end{array}$ \\
\hline happiness & $\begin{array}{l}0.0110^{* * * *} \\
(0.000366)\end{array}$ & $\begin{array}{c}0.00215 * * * \\
(0.000179)\end{array}$ & $\begin{array}{l}0.0114 * * * \\
(0.000385)\end{array}$ & $\begin{array}{l}0.0328 * * * \\
(0.000709)\end{array}$ & $\begin{array}{c}0.0235^{* * * *} \\
(0.00169)\end{array}$ & $\begin{array}{l}0.0200 * * * \\
(0.00162)\end{array}$ & $\begin{array}{c}0.0185^{* * * *} \\
(0.00175)\end{array}$ & $\begin{array}{c}0.00764 * * * \\
(0.00122)\end{array}$ & $\begin{array}{c}0.00963 * * * \\
(0.000410)\end{array}$ & $\begin{array}{l}-0.000227 \\
(0.000206)\end{array}$ \\
\hline Educ mother & $\begin{array}{c}-0.00166 * * * \\
(0.000169)\end{array}$ & $\begin{array}{c}-0.000364 * * * \\
(7.97 \mathrm{e}-05)\end{array}$ & $\begin{array}{c}-0.00324 * * * \\
(0.000188)\end{array}$ & $\begin{array}{l}-0.0132 * * * \\
(0.000379)\end{array}$ & $\begin{array}{l}0.00200 * \\
(0.00104)\end{array}$ & $\begin{array}{c}0.00155 \\
(0.00100)\end{array}$ & $\begin{array}{c}0.00348 * * * \\
(0.00102)\end{array}$ & $\begin{array}{c}0.00420 * * * \\
(0.000677)\end{array}$ & $\begin{array}{c}-0.00335^{* * *} * \\
(0.000210)\end{array}$ & $\begin{array}{c}-0.000596 * * * \\
(0.000121)\end{array}$ \\
\hline Educ father & $\begin{array}{c}-0.00178 * * * \\
(0.000166)\end{array}$ & $\begin{array}{c}-0.000256^{* * *} * \\
(7.75 \mathrm{e}-05)\end{array}$ & $\begin{array}{c}-0.00223 * * * \\
(0.000182)\end{array}$ & $\begin{array}{c}-0.00621 * * * \\
(0.000366)\end{array}$ & $\begin{array}{l}-0.00179 * \\
(0.000923)\end{array}$ & $\begin{array}{c}-0.00100 \\
(0.000892)\end{array}$ & $\begin{array}{c}-0.00264 * * * \\
(0.000912)\end{array}$ & $\begin{array}{c}-0.00277 * * * \\
(0.000624)\end{array}$ & $\begin{array}{c}-0.00207 * * * \\
(0.000202)\end{array}$ & $\begin{array}{c}-0.000961 * * * \\
(0.000115)\end{array}$ \\
\hline Observations & 156,411 & 156,411 & 156,411 & 156,411 & 35,902 & 35,902 & 35,902 & 35,902 & 156,411 & 156,411 \\
\hline
\end{tabular}

Robust standard errors in parentheses$$
* * * \mathrm{p}<0.01, * * \mathrm{p}<0.05, * \mathrm{p}<0.1
$$

Source: Author's calculations based on ECV 2018

We believe that technology adoption is a complex issue that is influenced by several variables, and we propose a technology adoption model that includes a social variable that is defined by how satisfied you are with life and person variables (e.g., age, sex), attitude variables, and parents' abilities. In addition, the adoption of new technologies usually requires new learning, and learning is influenced by individual differences in cognitive abilities [76-77].

We expected lower levels of education to be linked to lower levels of crystallized intelligence, higher levels of computer anxiety, and lower levels of computer self-efficacy, which in turn would be linked to lower levels of technology adoption. Our theoretical model includes direct paths between age and technology adoption and between education and technology adoption, anticipating the likelihood that the effects of age and education are not fully explained by the attitude and skill factors included in our study. 
Table 3. ATT results for different treatments on wages

\begin{tabular}{|c|c|c|c|c|c|c|c|c|c|c|}
\hline \multirow[b]{3}{*}{ VARIABLES } & \multirow[b]{3}{*}{ Use Compute } & (2) & (3) & \multicolumn{2}{|r|}{ (5) } & (6) & (7) & (8) & \multirow{2}{*}{$\begin{array}{c}(9) \\
\text { Internet }\end{array}$} & \multirow{2}{*}{$\begin{array}{c}(10) \\
\text { Radio }\end{array}$} \\
\hline & & & & Use & & & & & & \\
\hline & & ter Use Lapt & op Use Tabl & let Interne & Exce & Transfe & er Computation & nal Language & learning & Learning \\
\hline \multirow[t]{2}{*}{ Unmatched } & $0.564 * * *$ & $0.657 * *$ & $* \quad 0.449 * *$ & * $\quad 0.529 *$ & $* * 0.270 *$ & $* * * 0.291 * *$ & $0.201 * * *$ & 0.0376 & $0.510 * * *$ & $0.235^{* * * *}$ \\
\hline & $(0.0203)$ & $(0.0228)$ & $(0.0546)$ & $(0.015$ & $(0.034$ & 45) $\quad(0.0367$ & $(0.0312)$ & $(0.0403)$ & $(0.0216)$ & $(0.0536)$ \\
\hline \multirow[t]{2}{*}{ Constant } & $13.34 * * *$ & $13.36^{* *}$ & $* \quad 13.44 * * *$ & * $\quad 13.18 *$ & $* * \quad 13.60 *$ & $* * * 13.57 * *$ & $13.69 * * *$ & $13.78 * * *$ & $13.37 * * *$ & $13.45 * * *$ \\
\hline & $(0.00892)$ & $(0.00864$ & 4) $\quad(0.00817$ & $(0.0113$ & $(0.029$ & 92) $\quad(0.0321$ & (0.0217) & $(0.0172)$ & $(0.00879)$ & (0.00818) \\
\hline Observations & 37,004 & 37,004 & 37,004 & 37,00 & 15,17 & 15,179 & 15,179 & 15,179 & 37,004 & 37,004 \\
\hline \multirow[t]{3}{*}{ R-squared } & 0.021 & 0.022 & 0.002 & 0.029 & 0.00 & 0.004 & 0.003 & 0.000 & 0.015 & 0.001 \\
\hline & (1) & (2) & (3) & (4) & (5) & (6) & (7) & (8) & (9) & (10) \\
\hline & Use & & & Use & & & & & & Radio \\
\hline VARIABLES & Computer & Use Laptop & Use Tablet & Internet & Excel & Transfer & Computational & Language Inte & ernet learning & Learning \\
\hline \multirow[t]{2}{*}{ ATT } & $0.483^{* * *}$ & $0.478 * * *$ & $0.248 * * *$ & $0.498 * * *$ & $0.273 * * *$ & $0.292 * * *$ & $0.191 * * *$ & -0.0202 & $0.469 * * *$ & $0.168^{*}$ \\
\hline & $(0.0421)$ & $(0.0478)$ & $(0.0882)$ & $(0.0278)$ & $(0.0427)$ & $(0.0685)$ & $(0.0532)$ & $(0.0787)$ & $(0.0454)$ & $(0.0915)$ \\
\hline Observations & 37,004 & 37,004 & 37,004 & 37,004 & 15,179 & 15,179 & 15,179 & 15,179 & 37,004 & 37,004 \\
\hline
\end{tabular}

Standard errors in parenthesis $* * * \mathrm{p}<0.01 * * \mathrm{p}<0.05 * \mathrm{p}<0.1$

Source: Author's calculations based on ECV 2018

Except for programming languages, the use of technology and communication resources has a positive impact on wages (Table 3). Using laptops, the internet frequently and as learning resources have a significant impact than other technologies. On the contrary, the effect of using radio for learning has the least impact on wages (See Appendix B1). These results may vary if the level of development of the country under study is taken into account. [78]. 
Table 4. ATT results for different treatments on the level of education.

\begin{tabular}{|c|c|c|c|c|c|c|c|c|c|c|}
\hline \multirow[b]{3}{*}{ VARIABLES } & \multirow{2}{*}{\multicolumn{2}{|c|}{$\begin{array}{l}(1) \\
\text { Use }\end{array}$}} & \multirow[t]{2}{*}{ (3) } & (4) & \multirow[t]{2}{*}{ (5) } & \multirow[t]{2}{*}{ (6) } & \multirow[t]{2}{*}{ (7) } & \multirow[t]{2}{*}{ (8) } & \multirow{2}{*}{$\begin{array}{c}\text { (9) } \\
\text { Internet }\end{array}$} & \multirow{2}{*}{$\begin{array}{c}\text { (10) } \\
\text { Radio }\end{array}$} \\
\hline & & & & Use & & & & & & \\
\hline & Computer & Use Laptop & Use Tablet & Internet & Excel & Transfer & Computational & Language & learning & Learning \\
\hline \multirow[t]{2}{*}{ Unmatched } & $4.722 * * *$ & $5.427 * * *$ & $4.199 * * *$ & $3.207 * * *$ & $2.660 * * *$ & $2.263^{* * *}$ & $2.007 * * *$ & $2.007 * * *$ & $3.906 * * *$ & $0.740 * * *$ \\
\hline & $(0.0243)$ & $(0.0263)$ & $(0.0630)$ & $(0.0129)$ & $(0.0332)$ & $(0.0355)$ & $(0.0348)$ & $(0.0502)$ & $(0.0243)$ & $(0.0470)$ \\
\hline \multirow[t]{2}{*}{ Constant } & $4.110 * * *$ & $4.128 * * *$ & $4.383 * * *$ & $3.539 * * *$ & $6.070 * * *$ & $6.157 * * *$ & $6.859 * * *$ & $7.370 * * *$ & $4.146^{* * *}$ & $4.416^{* * *}$ \\
\hline & $(0.00636)$ & $(0.00624)$ & $(0.00680)$ & $(0.00679)$ & $(0.0256)$ & $(0.0289)$ & $(0.0219)$ & $(0.0188)$ & $(0.00659)$ & $(0.00693)$ \\
\hline Observations & 149,960 & 149,960 & 149,960 & 149,960 & 30,685 & 30,685 & 30,685 & 30,685 & 149,960 & 149,960 \\
\hline R-squared & 0.201 & 0.221 & 0.029 & 0.293 & 0.173 & 0.117 & 0.098 & 0.050 & 0.147 & 0.002 \\
\hline
\end{tabular}

\begin{tabular}{|c|c|c|c|c|c|c|c|c|c|c|}
\hline & (1) & (2) & (3) & (4) & (5) & (6) & (7) & (8) & (9) & (10) \\
\hline & Use & Use & & Use & & & & & Internet & Radio \\
\hline VARIABLES & Computer & Laptop & Use Tablet & Internet & Excel & Transfer & Computational & Language & learning & Learning \\
\hline \multirow[t]{2}{*}{ ATT } & $3.216 * * *$ & $3.834 * * *$ & $2.552 * * *$ & $2.418 * * *$ & $2.514 * * *$ & $2.269 * * *$ & $1.865 * * *$ & $1.797 * * *$ & $2.579 * * *$ & $0.387 * * *$ \\
\hline & $(0.0683)$ & $(0.0499)$ & $(0.117)$ & $(0.0357)$ & $(0.0478)$ & $(0.0636)$ & $(0.0676)$ & $(0.0778)$ & $(0.0709)$ & $(0.0737)$ \\
\hline Observations & 149,960 & 149,960 & 149,960 & 149,960 & 30,685 & 30,685 & 30,685 & 30,685 & 149,960 & 149,960 \\
\hline
\end{tabular}

Standard errors in parenthesis $* * * \mathrm{p}<0.01 * * \mathrm{p}<0.05 * \mathrm{p}<0.1$

Source: Author's calculations based on ECV 2018

Over the highest educational level achieved, the use of technological devices has an advantage in the impact of the years of schooling achieved (Table 4). Using computers, laptops, tablets, and the Internet often have a positive impact on the educational level, in a greater proportion than the use of radio for learning or programming languages. In fact, previous studies such as that by Machin and Van Reenen [79] showed that ICT complements the skills of the more educated workers, who have a particular advantage in using ICT effectively. It can be said that the new technologies may have shifted the demand towards more qualified workers.

\section{Discussion}

The results of this research correspond to the discourse that technological advances have been responsible for an increase in wages. However, it should not be ruled out that in some scenarios technology does not achieve these results because lower and middle-class jobs use their resources for other priorities or simply these classes have historically frequented a scenario of economic inequality and access to technological resources. They say that the remedy lies in wealth redistribution policies, or ICT promotion programs in the most vulnerable sectors (for example, "Computadores para educar" in Colombia). Encouraging these types of strategies is important because the absorption of knowledge by families allows many ordinary workers to finally see strong salary growth thanks to the acquisition and absorption of new technologies.

We are sure that information technology automates the work of jobs, and the pace of change is faster. However, the key challenge is that to implement important new technologies, large numbers of people have to learn new skills and knowledge. This learning turns out to be slow and difficult for those who have never appropriated the use of technology, although we know from the results of this research that it is the key to increasing wages. The bottom line is that participants in today's 
workforce must overcome a technological hurdle before they can benefit from new technologies. Here's the grand policy design.

Beyond the impact, business models and technology continue to change, requiring continuous learning. The most capable workers are capable of teaching themselves, but the average worker cannot. Nor have the universities kept up; and many continue to focus on traditional learning. Education should also be aimed at combining the core of the profession, with the acquisition of complementary technological skills so that graduates see their salaries grow strongly along with their new skills.

In sum, firms are in high demand for workers with critical technical skills, they are willing to pay high wages for workers who have them, but very few workers do. So, the problem is not that technology has eliminated the need for midsize workers in general. There are new opportunities but seizing them is difficult. Overcoming that hurdle will take time, as well as policies that promote technical training, certify skills learned through experience, encourage employee mobility, and foster strong labor markets [80]

\section{Conclusions}

The relationship between technology and wages has been widely discussed, various models try to verify the causal relationships, finding contrasts in the results based on various factors such as the period of application of the study, the methodology, the level of development of the country and other variables that can be included such as social, person and attitude.

The results of the impact of the adoption of technology on wages are positive and significant for the Colombian case. We seek that the adoption of new technologies by individuals is not incipient and generates an impact on wages and years of schooling. The use of these technologies affects the demand for skills and therefore makes the worker more productive. It's best to be prepared: improve workers' skills, particularly those automated at a higher cost (e.g., social-emotional, and digital skills). In this, public policies are decisive to achieve significant changes in the Colombian case.

A relevant observation allows us to affirm that the use of these technologies affects the demand for skills and therefore makes the worker more productive, improving the skills of workers, particularly those automated at a higher cost, is one of the challenges, for example, in terms of social-emotional and digital skills.

These estimates opened a research gap that needs more depth to determine the relationship analysis between technology and raw wage, where they consider unobserved heterogeneity as the skills of workers, the characteristics of the industry and business, the spaces working, and the differences in productivity caused by them.

Finally, these results have important implications for the ongoing political debate on government investment in ICT infrastructure to boost productivity and wage growth. The returns to work experience, manifested in wages, are a race between learning on the job and the obsolescence of skills. Today, college graduates who specialize in technology-intensive courses are in demand in the market quickly, earn incomes equal to or above-average salary, and often outperform fasterchanging occupations as they gain experience.

\section{Patents}

There are no patents resulting from the work reported in this manuscript.

Author Contributions: Fernando Barrios organized the database and analyzed and interpreted the data regarding the use of new technologies and wages in The Quality-of-Life Survey (ECV). Diana Alvarez reviewed existing literature about this issue and actively drafted the outcome document. Nancy Milena Riveros reviewed the theoretical framework of the structural model through which the impact of new technologies on wages was evaluated and was a major contributor in writing the manuscript. Martha Castellanos reviewed the conclusions and discussions and was a major contributor in writing the manuscript. All authors have read and agreed to the published version of the manuscript.

Funding: This research received no external funding, and the APC was funded by Fundación Universitaria del Area Andina, Colombia. 
Institutional Review Board Statement: Not applicable.

Conflicts of Interest: The authors declare no conflict of interest. Also, the funders had no role in the design of the study; in the collection, analyses, or interpretation of data; in the writing of the manuscript, or in the decision to publish the results.

\section{Appendix B1. Common support for using technologies frequently.}
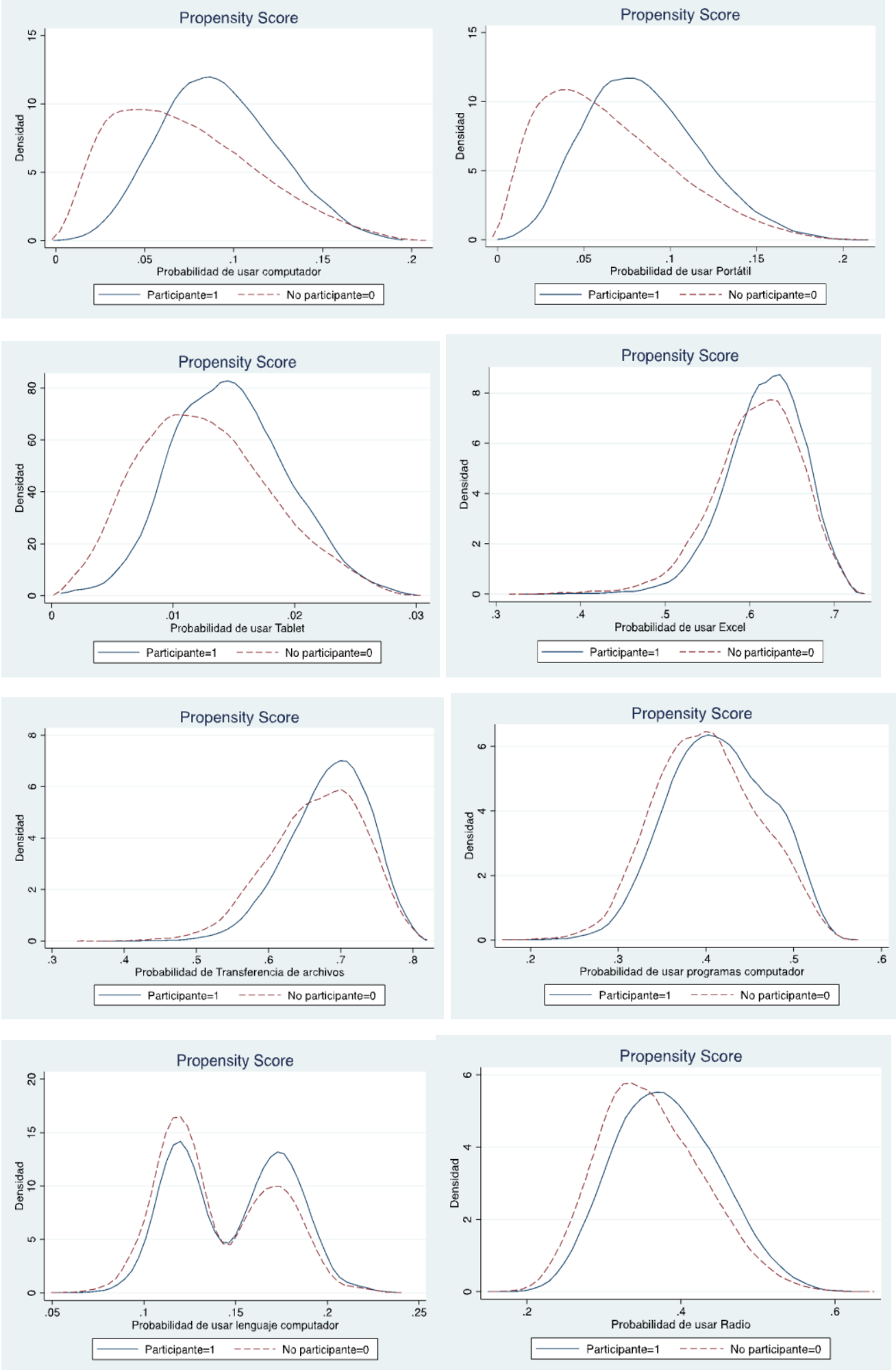


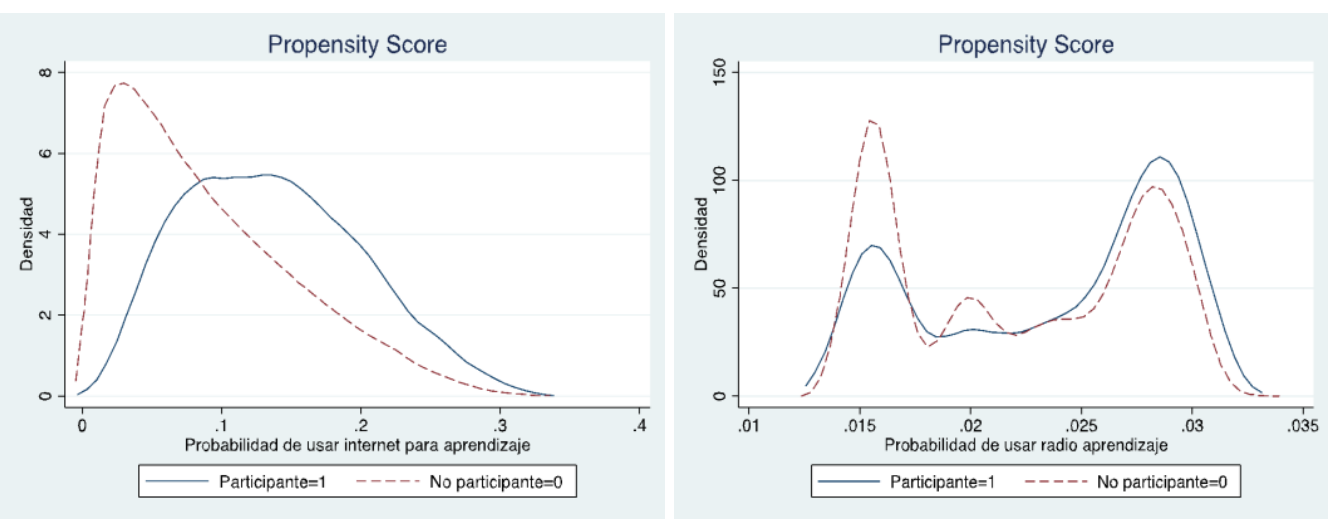

Source: Author's calculations based on ECV 2018

\section{References}

1. Rainie, L.; Anderson, J. The Future of Jobs and Jobs Training. Pew Research Center. Available online: https://eric.ed.gov/?id=ED591030 accessed on $7^{\text {th }}$. August, 2021.

2. Frey, \& Osborne. (2017). The future of employment: how susceptible are jobs to computerization? Technological Forecasting and Social Change, Volumen 114, pp. 254-280. https://doi.org/10.1016/j.techfore.2016.08.019

3. World Bank (2021). Are you afraid of labor robotization? Available online: https://www.bancomundial.org/es/news/feature/2017/07/11/robotizacion-mercado-trabajo. (accessed on $7^{\text {th }}$. August, 2021).

4. Acemoglu, D.; Restrepo, P. Automation and New Tasks: How Technology Displaces and Reinstates Labor. Journal of Economic Perspectives, Volumen 33 (2): 3-30. DOI: 10.1257/jep.33.2.3

5. Frey, \& Osborne. The future of employment: how susceptible are jobs to computerization? Technological Forecasting and Social Change, Volumen 114, pp. 254-280. https://doi.org/10.1016/j.techfore.2016.08.019

6. Zoghi, C; Pabilonia, S. Which workers gain upon adopting a computer?. Canadian Journal of Economics / Revue canadienne d'économique. 2007; Volumen 40. Page range: 423-444. https://doi.org/10.1111/j.1365-2966.2007.00415.x

7. Acemoglu, Daron \& Autor, David. Skills, Tasks and Technologies: Implications for Employment and Earnings, Handbook of Labor Economics, in: O. Ashenfelter \& D. Card (ed.), Handbook of Labor Economics, edition 1, volume 4, chapter 12, pages 10431171, Elsevier. https://doi.org/10.1016/S0169-7218(11)02410-5

8. Blinder, A., \& Krueger, A. Alternative Measures of Offshorability: A Survey Approach. Journal of Labor Economics. Volumen 31(2), pages S97-S128. doi:10.1086/669061.

9. Arabsheibani, G. Reza, Emami, J. M. \& Marin, Alan. The impact of computer use on earnings in the UK. Scottish Journal of Political Economy, Volumen 51 (1). pp. 82-94. ISSN 0036-9292. https://doi.org/10.1111/j.0036-9292.2004.05101005.x

10. Peng, G \& Zhang, D. Does Information Technology Substitute for or Complement Human Labor? A Dynamic Stratified Analysis on European Countries. Decision Sciences. 2019; Volumen 51 (3) pp: 720-754. https://doi.org/10.1111/deci.12357

11. Van der Velde, L. Within Occupation Wage Dispersion and the Task Content of Jobs. Oxf Bull Econ Stat 2020; Volumen 82 (5) pp: 1161-1197. https://doi.org/10.1111/obes.12368

12. Acemoglu, Daron. Why do new technologies complement skills? Directed technical change and wage inequality. The Quarterly Journal of Economics, 1998; Volumen 113 (4) pp: 1055-1089. https://doi.org/10.1162/003355398555838

13. Krueger, AB. How computers have changed the wage structure: Evidence from microdata, 1984-1989. Quarterly Journal of Economics. Volumen 108 (1) pp: 33-60. https://doi.org/10.2307/2118494

14. Deming, D \& Noray, K. Earnings dynamics, changing job skills, and stem careers. Quarterly Journal of Economics. Volumen 135 (4) pp: 1965-2005. https://doi.org/10.1093/qje/qjaa021

15. Arabsheibani, G. Reza; Marin, Alan \& Wadsworth, J. In the pink: Homosexual-heterosexual wage differentials in the UK. International Journal of Manpower. Volumen. 25 No. 3/4, pp. 343-354. https://doi.org/10.1108/01437720410541434.

16. Berman, E., Bound, J., \& Machin, S. Implications of Skill-Biased Technological Change: International Evidence. The Quarterly Journal of Economics. Volumen 113(4), pp: 1245-1279. Available online http://www.jstor.org/stable/2586980. (Accessed on August $2^{\text {nd. }}$, 2021). https://doi.org/10.1162/003355398555892

17. Goldin, C \& Katz, LF. The origins of technology-skill complementarity. QJ Econ 1998; Volumen 113 (3) pp: $692-732$. https://doi.org/10.1162/003355398555720

18. Krueger, AB. How computers have changed the wage structure: Evidence from microdata, 1984-1989. Quarterly Journal of Economics. Volumen 108 (1). pp: 33-60. https://doi.org/10.2307/2118494

19. DiNardo, J \& Pischke, J. The Returns to Computer Use Revisited: Have Pencils Changed the Wage Structure Too ?. Quarterly Journal of Economics, 112 (1). pp: 291-303. https://doi.org/10.1162/003355397555190

20. Arabsheibani, G. Reza, Emami, J. M. and Marin, Alan. The impact of computer use on earnings in the UK. Scottish Journal of Political Economy, Volumen 51 (1). pp. 82-94. ISSN 0036-9292. https://doi.org/10.1111/j.0036-9292.2004.05101005.x

21. Allen, S. Technology and the Wage Structure. Journal of Labor Economics. Volumen 19(2). pp: 440-483. doi:10.1086/319567.

22. Lee, S., \& Kim, J. "Has the Internet Changed the Wage Structure Too?", Labor Economics. Volumen. 11, No. 1, pp. 119-127. https://doi.org/10.1016/S0927-5371(03)00052-6 
23. Huesca L, Ochoa G. Wage Inequality And Technological Change Along The Northern Border Of Mexico. Development Problems 2016. Volumen 47 (187) pp: 165-188.

24. Torres García, AJ \& Ochoa Adame, GL. Wage inequality associated with the use of ICT in Mexico: An analysis by occupation. Quad Econ 2018. Volumen 37 (74): 353-390. https://doi.org/10.15446/cuad.econ.v37n74.56549

25. Oosterbeek $\mathrm{H}$, Ponce J. The impact of computer use on earnings in a developing country: Evidence from Ecuador. Labor Econ 2011; Volumen 18 (4) pp: 434-440. https://doi.org/10.1016/j.labeco.2010.11.002

26. Benavente, José M; Bravo, David \& Montero, Rodrigo. Wages and workplace computer use in Chile. Developing Economies 2011. Volumen 49 (4). pp: 382-403.https://doi.org/10.1111/j.1746-1049.2011.00144.x

27. Silva M. Tic y Desigualdad salarial en Uruguay. Institute of Economics. Fcea.edu.uy. 2016. Available online: http://fcea.edu.uy/Jornadas_Academicas/2016/Ponencias/Economia/Trabajos/MSilva-jja2016.pdf (accessed on 21st., March, 2021).

28. Navarro, L. The impact of internet use on individual earnings in Latin America " in ICT in Latin America: a microdata analysis, ECLAC, 2011. Volumen 11. pp: 69-93

29. Martin, DA. U-shaped wage curve and the internet: The Colombian case. Study Econ 2018. Volumen 45 (2).pp: $173-202$.

30. Botello Peñaloza, H. A; Pedraza Avella, A.C \& Contreras Pacheco, OE. Business Analysis of the influence of ICT on the performance of service companies in Colombia. Virtual Magazine Universidad Católica del Norte. 2015. Volumen 45. pp: 3-15.

31. Acemoglu, Daron \& Autor, David.. Skills, Tasks and Technologies: Implications for Employment and Earnings, Handbook of Labor Economics, in: O. Ashenfelter \& D. Card (ed.), Handbook of Labor Economics. Edition 1. Volume 4, chapter 12. pp: 10431171, Elsevier. https://doi.org/10.1016/S0169-7218(11)02410-5

32. Author, David; Levy, Frank \& Murnane, Richard (2003). The Skill Content of Recent Technological Change: An Empirical Exploration," The Quarterly Journal of Economics, Oxford University Press, vol. 118(4), pages 1279-1333. https://doi.org/10.1162/003355303322552801

33. Blinder, A., \& Krueger, A. Alternative Measures of Offshorability: A Survey Approach. Journal of Labor Economics. Volumen 31(2). pp: S97-S128. doi:10.1086/6690

34. Author, David; Levy, Frank \& Murnane, Richard. The Skill Content of Recent Technological Change: An Empirical Exploration," The Quarterly Journal of Economics, Oxford University Press. Volumen. 118(4). pp: 1279-1333. https://doi.org/10.1162/003355303322552801

35. Author, David H., Katz, Lawrence F \& Krueger, Alan B. Computing Inequality: Have Computers Changed the Labor Market?, The Quarterly Journal of Economics. Volumen 113. pp: 1169-1213, https://doi.org/10.1162/003355398555874

36. Acemoglu, Daron. Why do new technologies complement skills? Directed technical change and wage inequality. The Quarterly Journal of Economics, 1998; Volumen 113 (4) pp: 1055-1089. https://doi.org/10.1162/003355398555838

37. Krueger, AB. How computers have changed the wage structure: Evidence from microdata, 1984-1989. Quarterly Journal of Economics. Volumen 108 (1) pp: 33-60. https://doi.org/10.2307/2118494

38. Arabsheibani, G. Reza, Emami, J. M. \& Marin, Alan. The impact of computer use on earnings in the UK. Scottish Journal of Political Economy, Volumen 51 (1). pp. 82-94. ISSN 0036-9292. https://doi.org/10.1111/j.0036-9292.2004.05101005.x

39. Bound, J., \& Johnson, G. Changes in the Structure of Wages in the 1980's: An Evaluation of Alternative Explanations. The American Economic Review. Volumen 82(3). pp: 371-392. Available online http://www.jstor.org/stable/2117311. (accessed on 2nd. August, 2021). DOI 10.3386/w2983

40. Bresnahan, Timothy, Brynjolfsson, Erik and Hitt, Lorin M. Information Technology, Workplace Organization, and the Demand for Skilled Labor: Firm-Level Evidence, The Quarterly Journal of Economics, 117. pp: 339-376, https://EconPapers.repec.org/RePEc:oup:qjecon:v:117:y:2002:i:1:p:339-376. DOI:10.1162/003355302753399526

41. Goldin, C \& Katz, LF. The origins of technology-skill complementarity. QJ Econ $1998 . \quad$ pp: $692-732$. https://doi.org/10.1162/003355398555720

42. Krueger, AB. How computers have changed the wage structure: Evidence from microdata, 1984-1989. Quarterly Journal of Economics. Volumen 108 (1) pp: 33-60. https://doi.org/10.2307/2118494

43. DiNardo, J \& Pischke, J. The Returns to Computer Use Revisited: Have Pencils Changed the Wage Structure Too ?. Quarterly Journal of Economics, 112 (1). pp: 291-303. https://doi.org/10.1162/003355397555190

44. Arabsheibani, G. Reza, Emami, J. M. \& Marin, Alan. The impact of computer use on earnings in the UK. Scottish Journal of Political Economy, Volumen 51 (1). pp. 82-94. ISSN 0036-9292. https://doi.org/10.1111/j.0036-9292.2004.05101005.x

45. Huesca L, Ochoa G. Wage Inequality And Technological Change Along The Northern Border Of Mexico. Development Problems 2016. Volumen 47 (187) pp: 165-188.

46. Torres García, AJ \& Ochoa Adame, GL. Wage inequality associated with the use of ICT in Mexico: An analysis by occupation. Quad Econ 2018. pp: 353-390. https://doi.org/10.15446/cuad.econ.v37n74.56549

47. Oosterbeek H, Ponce J. The impact of computer use on earnings in a developing country: Evidence from Ecuador. Labor Econ 2011; Volumen 18 (4) pp: 434-440. https://doi.org/10.1016/j.labeco.2010.11.002

48. Benavente, José M; Bravo, David \& Montero, Rodrigo. Wages and workplace computer use in Chile. Developing Economies 2011. Volumen 49 (4). pp: 382-403.https://doi.org/10.1111/j.1746-1049.2011.00144.x

49. Martin, DA. U-shaped wage curve and the internet: The Colombian case. Study Econ 2018. Volumen 45 (2). pp: $173-202$.

50. Bound, J., \& Johnson, G. Changes in the Structure of Wages in the 1980's: An Evaluation of Alternative Explanations. The American Economic Review. Volumen 82(3). pp: 371-392. Available online http://www.jstor.org/stable/2117311. (accessed on 2nd. August, 2021). DOI 10.3386/w2983 
51. Acemoglu, Daron. Why do new technologies complement skills? Directed technical change and wage inequality. The Quarterly Journal of Economics, 1998. Volumen 113 (4). pp: 1055-1089. https://doi.org/10.1162/003355398555838

52. Author, David; Levy, Frank \& Murnane, Richard. The Skill Content of Recent Technological Change: An Empirical Exploration," The Quarterly Journal of Economics, Oxford University Press. Volumen. 118(4). pp: 1279-1333. https://doi.org/10.1162/003355303322552801

53. Beaudry, Paul., Doms, Mark., \& Lewis, Ethan. Should the personal computer be considered a technological revolution? Evidence from US metropolitan areas. Journal of Political Economy. Volumen 118(5). pp: 988-1036. https://doi.org/10.1086/658371

54. Acemoglu, Daron \& Autor, David.. Skills, Tasks and Technologies: Implications for Employment and Earnings, Handbook of Labor Economics, in: O. Ashenfelter \& D. Card (ed.), Handbook of Labor Economics. Edition 1. Volume 4, chapter 12. pp: 10431171, Elsevier. https://doi.org/10.1016/S0169-7218(11)02410-5

55. Michaels, G., Natraj, A., \& Van Reenen, J. . Has ICT polarized skill demand? Evidence from eleven countries over twenty-five years. Review of Economics and Statistics, 96(1). pp: 60-77. https://doi.org/10.1787/1621d67f-en

56. Iacovone, L., \& Pereira-Lopez, M. ICT Adoption and Wage Inequality: Evidence from Mexican Firms. Background paper for the Regional Study on Digital Technology Adoption, Skills, Productivity and Jobs in Latin America. The World Bank. Available online: https://openknowledge.worldbank.org/handle/10986/29161. (accessed on 7th August, 2021).

57. Acemoglu, Daron, and Restrepo, Pascual. Automation and New Tasks: How Technology Displaces and Reinstates Labor. Journal of Economic Perspectives, 33 (2).pp: 3-30. DOI: 10.1257/jep.33.2.3

58. Krueger, AB. How computers have changed the wage structure: Evidence from microdata, 1984-1989. Quarterly Journal of Economics. Volumen 108 (1) pp: 33-60. https://doi.org/10.2307/2118494

59. DiNardo, J \& Pischke, J. The Returns to Computer Use Revisited: Have Pencils Changed the Wage Structure Too ?, Quarterly Journal of Economics, 112 (1). pp: 291-303. https://doi.org/10.1162/003355397555190

60. Doms, M., Dunne, T., \& Troske, K. R. Workers, wages, and technology. The Quarterly Journal of Economics. Volumen 112(1) pp:253-290. https://doi.org/10.1162/003355397555181

61. Allen, S. Technology and the Wage Structure. Journal of Labor Economics. Volumen 19(2). pp: 440-483. doi:10.1086/319567.

62. Arabsheibani, G. Reza, Emami, J. M. \& Marin, Alan. The impact of computer use on earnings in the UK. Scottish Journal of Political Economy, Volumen 51 (1). pp. 82-94. ISSN 0036-9292. https://doi.org/10.1111/j.0036-9292.2004.05101005.x

63. Zoghi, C; Pabilonia, S. Which workers gain upon adopting a computer?. Canadian Journal of Economics / Revue canadienne d'économique. 2007; Volumen 40. Page range: 423-444. https://doi.org/10.1111/j.1365-2966.2007.00415.x

64. Störmer, E., Patscha, C., Prendergast, J., Daheim, C., Rhisiart, M., Glover, P., \& Beck, H. The future of work: jobs and skills in 2030. UK Commisson for Employment and Skills (UKCES). DOI:10.13140/RG.2.1.3063.8241

65. Akerman, Anders, Gaarder, Ingvil, \& Mogstad, Magne. The skill complementarity of broadband internet. The Quarterly Journal of Economics, Oxford University Press. Volumen 130(4), pp: 1781-1824. https://doi.org/10.1093/qje/qjv028

66. Caliendo, M., \& Kopeinig, S. Some practical guidance for the implementation of propensity score matching. Journal of Economic Surveys. Volumen 22(1). pp: 31-72. https://doi.org/10.1111/j.1467-6419.2007.00527.x

67. Benavente, José M; Bravo, David \& Montero, Rodrigo. Wages and workplace computer use in Chile. Developing Economies 2011. Volumen 49 (4). pp: 382-403.https://doi.org/10.1111/j.1746-1049.2011.00144.x

68. Navarro, L.. The impact of internet use on individual earnings in Latin America. ICT in Latin America: a microdata analysis, ECLAC. 2011. Volumen 11. pp: 69-93

69. Martin, DA. U-shaped wage curve and the internet: The Colombian case. Study Econ 2018. Volumen 45 (2). pp: $173-202$.

70. Novella, R., Alvarado, A., Rosas, D., González-Velosa, C. Encuesta de habilidades al trabajo (ENHAT) 2017-2018: Causas y consecuencias de la brecha de habilidades en Perú. Washington DC: Inter-American Development Bank.

71. Silva M. Tic y Desigualdad salarial en Uruguay. Institute of Economics. Fcea.edu.uy. 2016. Available online: http://fcea.edu.uy/Jornadas_Academicas/2016/Ponencias/Economia/Trabajos/MSilva-jja2016.pdf (accessed on 21st., March, 2021).

72. Frey, \& Osborne. The future of employment: how susceptible are jobs to computerisation? Technological Forecasting and Social Change, Volumen 114. pp: 254-280. https://doi.org/10.1016/j.techfore.2016.08.

73. Lee, S., \& Kim, J. Has the Internet Changed the Wage Structure Too?. Labor Economics, Volumen. 11. pp: 119-127. https://doi.org/10.1016/S0927-5371(03)00052-6

74. Dutz, M. A., Mation, L. F., O'Connell, S. D., \& Willig, R. D.. Economy-wide and sectoral impacts on workers of Brazil's internet rollout. The World Bank. https://doi.org/10.1080/07360932.2017.1307137

75. Brassiolo, Pablo Nahirñak, Paula Ruffo, Hernán. Uso y adopción de tecnología informática en el mercado laboral de Argentina. Instituto de Estudios sobre la Realidad Argentina y Latinoamérica (IERAL). Available online: https://aaep.org.ar/anales/works06/Brassiolo_Nahirnak_Ruffo.pdf. (accessed on 5th. August, 2021).

76. Rogers, WA; Hertzog, C \& Fisk, AD. An Individual Differences Analysis of Ability and Strategy Influences: Age-Related Differences in Associative Learning. J Exp Psychol Learn Mem Cogn 2000. Volumen 26 (2). pp: $359-394$. https://doi.org/10.1111/deci.1235

77. Beier ,Margaret E, Ackerman Phillip L. Age, ability, and the role of prior knowledge on the acquisition of new domain knowledge: Promising results in a real-world learning environment. Psychol Aging 2005. Volumen 20 (2) pp: 341-355. https://doi.org/10.1037/0882-7974.20.2.341

78. Brassiolo, Pablo Nahirñak, Paula Ruffo, Hernán. Uso y adopción de tecnología informática en el mercado laboral de Argentina. Instituto de Estudios sobre la Realidad Argentina y Latinoamérica (IERAL). Available online: https://aaep.org.ar/anales/works06/Brassiolo_Nahirnak_Ruffo.pdf. (accessed on 5th. August, 2021). 
79. Macheen, S. \& Van, J. Reenen. Changes in wage inequality. Center for economics performance. Available online https://www.researchgate.net/profile/John-

Reenen/publication/5001231_Changes_in_Wage_Inequality/links/02e7e51ffd7b76500f000000/Changes-in-Wage-Inequality.pdf. (accessed on 5th. August, 2021).

80. Bessen, James. How Technology Has Affected Wages for the Last 200 Years. Harvard Business Review 